\title{
Lokative pronominer og præpositionalfrasens struktur ${ }^{1}$
}

\section{Michael Nguyen}

\begin{abstract}
In this paper, I investigate the syntax of the prepositional phrase in Danish and the locative pronouns her 'here', der 'there' and hoor 'where' in e.g. hertil 'hereto'. I argue that (a) the directional adverb $\mathrm{p}$ is a functional head that projects a $\mathrm{pP}$ on top of a PP and takes this PP as its complement; that (b) the locative pronoun moves via an intermediate position within the prepositional phrase before it leaves the prepositional phrase; and that (c) the preposition moves to $\mathrm{p}$ (P-to-p-incorporation).
\end{abstract}

\section{Nøgleord}

præpositioner, præpositionalfraser, præpositionsstranding, funktionelle projektioner, lokative pronominer

\section{Indledning}

I denne artikel behandler jeg en række aspekter af præpositionalfrasens syntaks. Først og fremmest vil jeg argumentere for strukturen der er vist med kantede parenteser i (1) og med et strukturtræ i (2). I (3) er den eksemplificeret.

$$
\left[_{\mathrm{pP}} \mathrm{P}\left[{ }_{\mathrm{PP}}[\mathrm{P} \mathrm{XP}]\right]\right]
$$

1 Tak til Kasper Boye, Elisabet Engdahl, Lars Heltoft, Henrik Jørgensen, Paul Law, Sten Vikner og deltagerne ved konferencen Grammatiknetverket i 2018 for kommentarer og frugtbar diskussion. 


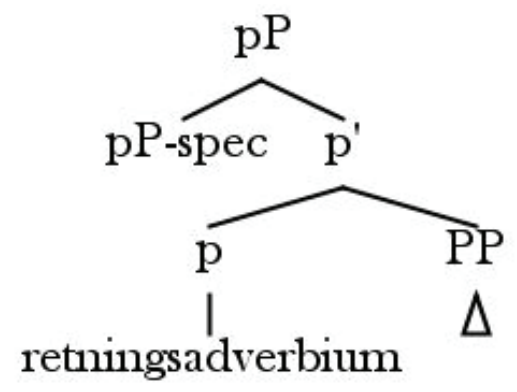

Han sprang ${ }_{\mathrm{pP}}$ ind $\left[{ }_{\mathrm{PP}}\right.$ i skabet]

Det centrale i strukturen er at retningsadverbiet, $\mathrm{fx}$ ind, ud, oppe og henne, står i lille p og tager en PP som komplement. Lignende strukturer er foreslået i fx Rooryck (1996), Den Dikken (2010), Koopman (2000), Riemsdijk (1990) og Riemsdijk \& Huijbregts (2007); se også Cinque (1999: 137-139). At denne struktur findes i dansk, vil jeg argumentere for i afsnit 2.

Derudover vil jeg behandle de lokativer pronominer her, der og hoor i forbindelse med præpositionalfrasens syntaks. Jeg vil argumentere for at disse pronominer flytter gennem en mellemlandingsposition inden for præpositionalfrasen inden de forlader den helt (afsnit 3).

Jeg vil desuden argumentere for at præpositionen P flytter op i p (eller 'inkorporerer' i p) og derved skaber et slags komplekst præpositionelt kompositum (afsnit 4).

Der skal siges et par ord om den terminologi jeg i det følgende vil bruge.

Begrebet 'præpositionalfrase' bruges både om pP'er og om nøgne PP'er, som ikke har et pP-lag over sig. Det vil altså sige at pPi $(1) /(2)$ og (3) omtales som en præpositionalfrase, mens indlejrede PP'er ikke gør. Begrebet bruges om hele det præpositionelle domæne, uanset om dette domæne blot er en nøgen PP eller en pP i den givne situation.

Begrebet 'lokativt pronomen' bruges om her, der og hvor når de forekommer i tæt forbindelse med P, fx herfra og hertil; se Nguyen (2017: 9) for en liste over sådanne forbindelser. Lokative pronominer kaldes også 'R-pronominer' i den internationale litteratur. Begrebet stammer fra Riemsdijk (1978), der undersøger lignende pronominer i nederlandsk. Disse indeholder et $r$-fonem, heraf betegnelsen.

Lokative pronominer kan deles op i dem som kan adskilles fra $\mathrm{P}$, og dem der ikke kan. Den førstnævnte gruppe betegner noget spatialt; den sidstnævnte gør ikke, fx Effekten, hoormed kraften udforer arbejde under åbningen 
[... $]^{2}$ (Hansen \& Heltoft 2011: 846-553; Nguyen 2017). I denne artikel behandler jeg kun de spatiale lokative pronominer.

\section{Argumenter for pP-strukturen}

Først vil jeg argumentere for strukturen $\mathrm{i}(1) /(2)$, altså at retningsadverbiet $\mathrm{p}$ er eller kan være kerne i præpositionalfrasen, og at p plus den efterfølgende PP er en konstituent. For en god ordens skyld oplister jeg her de elementer der kan stå i p (de dynamiske ateliske former, fx nedad, behandler jeg ikke):

\begin{tabular}{|l|l|}
\hline Dynamisk & Statisk \\
\hline hen & henne \\
\hline hjem & hjemme \\
\hline ind & inde \\
\hline ned & nede \\
\hline over & ovre \\
\hline om & omme \\
\hline op & oppe \\
\hline ud & ude \\
\hline
\end{tabular}

Tabel 1.

(Udbygget efter Hansen \& Heltoft 2011: 838)

De følgende argumenter i afsnit 2.1 - 2.3 understøtter eksistensen af pPstrukturen i $(1) /(2)$.

\subsection{Retningsadverbiet $p$ er en kerne}

I pP-strukturen er p en kerne, og kerner er obligatoriske. Hvis p er obligatorisk, er det sandsynligvis en kerne. Ifølge Hovmark (2007: 182-184) er $\mathrm{p}$ så godt som obligatorisk når komplementet til $\mathrm{P}$ refererer til en person. I følgende sætning refererer P-komplementet til to personer, og følgelig er p hen obligatorisk: ${ }^{3}$

2 Eksemplet er fra https://www.sctknud-gym.dk/media/151991/fysik-a.pdf.

3 Asterisken i (4) og (5) og de to spørgsmålstegn i (6) angiver at sætningerne er hhv. ugrammatiske og degraderede hvis elementet i parentes ikke er til stede. En anonym fagfællebedømmer mener ikke at hen er obligatorisk i (4), men det er jeg uenig i, og øjensynlig også Hovmark (2007: 182184). Googlesøgninger viser da også at der er meget færre eksempler på strengene skal til ham/ hende end skal hen til ham/hende. Fagfællebedømmeren nævner også Kobmanden flyttede på landet som en velformet version af (6). At sætningen er velformet, kan skyldes at at flytte på landet til en vis grad er idiomatisk og kun kan betyde at fytte $\boldsymbol{u d}$ på landet. Derfor er det plausibelt at antage at der er et usynligt $\mathrm{p} u d, \mathrm{og}$ at det er det der licenserer det direktionelle i Kobmanden flyttede på landet. Tilstedeværelsen af et tilsvarende usynligt p er mindre sandsynlig i (6). 
Lille p er også mere eller mindre obligatorisk i følgende sætninger under en dynamisk og målrettet fortolkning (under en statisk fortolkning ville $\mathrm{p}$ ikke være obligatorisk):

(5) De svømmede *(ind) i fjorden.

(Sten Vikner pers. kommunikation)

Købmanden flyttede ??(hen) på hjørnet

(Sml. med Hansen \& Heltoft 2011: 842)

\subsection{Inkorporation og blokering af inkorporation $i$ verbet}

Det andet argument angår 'inkorporation' af p og $\mathrm{P}$ i verbet $\mathrm{V}$ og blokering heraf. Én slags inkorporation er den der sker på Logical Form (LF), se fx Zeller (1997). LF er et interface som genererer en semantisk repræsentation til overfladestrengen, dvs. efter at visse transformationer har fundet sted. Fx er det inkorporation af p i V på LF der gør at V og det inkorporerede p får én non-kompositionel betydning, fx sove ud eller gribe ind (fx i forhandlingerne). Denne form for inkorporation ser ud til at svare til en række tryktabsforbindelser (se fx Thomsen 1997).

I modsætning hertil bruger jeg i det følgende begrebet 'inkorporation' om en operation som foregår ved flytning i den synlige syntaks; dvs. at jeg antager at i hvert fald nogle orddannelser sker i syntaksen. For nærværende er det inkorporation af hhv. p og $\mathrm{P}$ i V der er relevant. ${ }^{4} \mathrm{Jeg}$ gennemgår først de mulige tilfælde af inkorporation i V.

I (7) inkorporerer p ud ikke i verbet sende, hvorimod (8) viser denne inkorporation, se formen $\boldsymbol{u d}$ sendt. (9) viser at $\mathrm{P}$ gennem ikke er inkorporeret $\mathrm{i}$ verbet rejse; (10) viser denne inkorporation, se formen gennemrejse:

4 Dette åbner for en Pandoras æske af komplikationer som jeg ikke behandler her. For det første er der forskellige typer af $\mathrm{p}, \mathrm{og}$ de overlapper i form og indhold. For det andet er det idiosynkratisk hvilke p'er der inkorporerer i V (Herslund 1984: 45ff; Svenonius 1996: 19). Et eksempel på disse komplikationer er strengen at løbe ind i nogen, som både kan betyde 'at møde nogen tilfældigt' eller 'at støde ind i nogen ved løb'. Hertil kommer verbet indløbe, som betyder noget i retning af 'at komme ind' eller 'at noget er modtaget', fx Ansøgningerne er indløbet. De tilfælde jeg beskæftiger mig med i denne artikel, er (nær)synonyme, uanset om p eller P inkorporerer i V eller ej. 
$\begin{array}{llll}\text { (7) De har sendt } & \begin{array}{l}\text { en meddelelse ud til befolkningen. } \\ \text { en meddelelse _ til befolkningen. }\end{array} \\ \text { (8) De har udsendt } & & \text { gennem } & \text { Tyskland. } \\ \text { (9) } & \text { De vil rejse } & \text { Tyskland. } \\ \text { (10) } & \text { De vil gennemrejse } & \text { (Tilpasset efter Herslund 1984: 44) }\end{array}$

(7) - (10) viser altså at det er muligt for både p og P at inkorporere i V. Dette er dog ikke altid tilfældet. (12) viser at $\mathrm{p}$ ned blokerer for at $\mathrm{P}$ gennem kan inkorporere i rejse, også selvom ned ikke selv er inkorporeret i rejse:

(11) De vil rejse
*De vil genn ned gennem

ned

emrejse

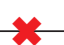

Tyskland.

Tyskland.

Disse to facts, muligheden for inkorporation af $\mathrm{p}$ og blokeringen af inkorporation af $\mathrm{P}$, understøtter $\mathrm{pP}$-strukturen: Lille p er højere oppe i strukturen og kan inkorporere i V, samtidig med at den blokerer for inkorporation af P. p’s høje position medfører blokering af inkorporation af en lavere kerne (i dette tilfælde P) fordi en kerne ikke kan flytte hen over en anden kerne. Dette er den såkaldte 'Head Movement Constraint' (HMC) (Travis 1984: 131). De relevante kerneflytninger kan illustreres således:

$$
\begin{aligned}
& \left.{ }_{\mathrm{VP}}[\mathrm{p}+\mathrm{V}]\left[_{\mathrm{pP}}-\left[{ }_{\mathrm{PP}} \mathrm{P} D \mathrm{DP}\right]\right]\right] \\
& \mathrm{VP}_{\mathrm{PP}}[\mathrm{P}+\mathrm{V}]\left[\left[_{\mathrm{PP}}-\mathrm{DP}\right]\right]
\end{aligned}
$$

(svarende til (7))

(svarende til (10)

(svarende til (12); flytningen er umulig pga. $\mathrm{HMC}$ )

Inkorporation af $\mathrm{p}$ i V ville yderligere kunne give andre rigtige forudsigelser. Dette hænger sammen med Bakers Government Transparency Corrolary (GTC), der siger (stærkt parafraseret og forenklet) at det morfologiske kompleks som dannes ved inkorporation, kommer til at styre alt hvad det element der undergår inkorporation, styrede inden det undergik inkorporation (Baker 1988: 63-68). Det medfører at det som det inkorporerede element styrede, bliver flytbart. 
Hvis p inkorporerer i V i (7), følger det ligeledes af GTC at den efterfølgende PP kan flytte. Det skyldes at p+V-komplekset styrer det tidligere komplement til p, dvs. PP. Sammenlign således (16a), hvor p er inkorporeret, med (16b), hvor det ikke er; kun i (16a) kan PP'en flytte:

(16a) Det er [p til befolkningen] at de har udsendt en meddelelse

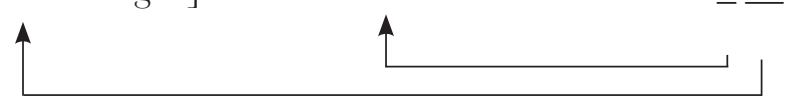

(16b) ??/* Det er [ ${ }_{\mathrm{PP}}$ til befolkningen] at de har sendt en meddelelse ud

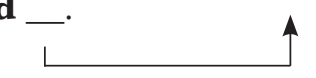

Dvs. at hvis det er rigtigt at $\mathrm{p}$ inkorporerer i V, ville dette kunne forklare hvorfor PP'en kan flytte i (16a). Dette er dog ikke nogen forklaring på hvorfor PP'en i grunden ikke kan flytte i (16b). ${ }^{5}$ Jeg foreslår i afsnit 4 at dette skyldes P-til-p-inkorporation.

Sten Vikner (pers. kommunikation) pointerer at inkorporation af p i V forudsiger at der ikke kan stå et andet $\mathrm{p}(\mathrm{fx}$ ned) på det påståede inkorporerede p's basisposition. Det ser rigtigt nok ud til at der er en degraderende effekt ved indsættelse af dette p, men om det skyldes syntaks, semantik eller stil, er et åbent spørgsmål:

$$
\text { ?/?? De har udsendt en meddelelse ned til befolkningen. }
$$

\subsection{Retningsadverbiet $p+$ PP er en konstituent}

Yderligere forudsiger strukturen i (1)/(2) at p og den efterfølgende PP tilsammen er en konstituent. Det tredje argument går således ud på at påvise dette. Kløvning samt forfelts-, koordinations- og elisionsprøven understøtter at 'p + PP' er en konstituent:

(18a) Det var [hen over gulvtæppet] at en sten rullede.

(18b) [Hen over gulvtæppet] rullede en sten.

5 Den anonyme fagfællebedømmer mener at (16b) er velformet. Dette hænger muligvis sammen med at det kan være tvetydigt om til befolkningen er søster til p $u d$, som i (1)/(2), eller om den er adjungeret højere oppe (se afsnit 4). Ved adjungering ville det være muligt at sætte PP'en i fokusposition under kløvning. 
(18c) En sten rullede [hen over gulvtæppet] og [ned i et hul].

(18d) En sten rullede hen over gutvtappet.

((18b) er fra KorpusDK)

(19a) Det var [henne på skolen] at vi lavede mange lektier.

(19b) [Henne på skolen] lavede vi mange lektier.

(19c) [Henne på skolen] og [inde på biblioteket] lavede vi mange lektier.

(19d) Vi lavede mange lektier henne på skolent.

\section{Ekstraktion gennem en mellemlandingsposition $i$ præpositionalfrasen ${ }^{6}$}

I dette afsnit argumenterer jeg for at flytning af lokative pronominer sker gennem en mellemlandingsposition i præpositionalfrasen (afsnit 3.1.). Derefter kommer jeg kort ind på en række udestående spørgsmål som analysen rejser (afsnit 3.2.).

\subsection{Evidens for ekstraktion gennem en mellemlandings- position $i$ prapositionalfrasen}

I dansk findes der en række P'er som er næsten synonyme med hinanden. De er givet i tabellen nedenfor:

\begin{tabular}{|l|l|}
\hline Ikke- $i$-præpositioner & $i$-præpositioner \\
\hline Mellem & Imellem \\
\hline Blandt & Iblandt \\
\hline Mod & Imod \\
\hline Gennem & Igennem \\
\hline
\end{tabular}

Tabel 2.

P'erne i højre spalte indeholder et $i$; det gør dem i venstre spalte ikke. I denne kontekst kalder jeg P'erne med $i$ for $i$-præpositioner og dem uden $i$ for ikke-i-præpositioner.

Den centrale forskel mellem $i$ - og ikke-i-præpositioner er at førstnævnte kan tage lokative pronominer, mens sidstnævnte ikke kan:

6 Dette afsnit er en omarbejdet version af Nguyen (2019). 


\begin{tabular}{|l|l|}
\hline Ikke-i-præpositioner & $i$-præpositioner \\
\hline *Dermellem & Derimellem \\
\hline *Derblandt & Deriblandt \\
\hline *Dermod & Derimod \\
\hline *Dergennem & Derigennem \\
\hline
\end{tabular}

Tabel 3 .

Denne kontrast vil jeg udnytte til at argumentere for at det lokative pronomen flytter til (og igennem) en position inden for præpositionalfrasen. Se følgende tabel:

\begin{tabular}{|l|l|l|}
\hline Lokativt pronomen $+\mathrm{p}$ & $\begin{array}{l}\text { Lokativt pronomen }+\mathrm{p}+ \\
\text { ikke- } i \text {-præposition }\end{array}$ & $\begin{array}{l}\text { Lokativt pronomen }+\mathrm{p}+i \text { - } \\
\text { præposition }\end{array}$ \\
\hline Derhen & *Derhenmellem & Derhenimellem \\
\hline Derind & *Derindmellem & Derindimellem \\
\hline Derned & *Dernedmellem & Dernedimellem \\
\hline Derop & *Deropmellem & Deropimellem \\
\hline Derud & *Derudmellem & Derudimellem \\
\hline
\end{tabular}

Tabel 4 .

Inden jeg argumenterer for intermediær flytning af det lokative pronomen, er der en komplikation som skal adresseres først: p kan i sig selv tage et lokativt pronomen, som det kan ses i første spalte i tabel 4, men af en eller anden grund er dette ikke muligt når det kombineres med en $\mathrm{P}$ som ikke tager et lokativt pronomen, se den midterste spalte i tabel 4. ${ }^{7}$ Det betyder antageligvis at det lokative pronomen i tredje spalte heller ikke er genereret af p. ${ }^{8}$ M.a.o. er der ingen grund til at antage at $\mathrm{p}$ ikke kan tage et lokativt pronomen når $\mathrm{P}$ er en ikke-i-præposition, hvorimod det godt kan hvis $\mathrm{P}$ er en $i$-præposition.

7 Det skal dog siges at jeg fandt 13 potentielle modeksempler med strengen ' $d e r+h e n+\bmod$ ' i Google.

8 Lars Heltoft (pers. kommunikation) har nævnt muligheden for mig at i hvert fald elementerne i tredje spalte af tabel 4 blot er leksikalske elementer - at de ikke har frasal status. Hvis de er leksikalske elementer, må de nødvendigvis bestå af flere rødder og dermed være komposita. Men $i$-præpositionerne danner generelt ikke komposita, i hvert fald ikke som første led, fx $\left(*_{i}\right)$ modstand $\mathrm{og}\left({ }^{*}\right)$ gennemskrive. Det betyder at analysen af at elementerne i tredje spalte er komposita, er mindre sandsynlig. Hvis de er komposita, ville man desuden ikke kunne forklare kontrasten mellem $i$ - og ikke-i-præpositionerne når det kommer til selekteringen af det lokative pronomen, både når det kombineres med $\mathrm{P}$ (derimellem versus *dermellem), og når det kombineres med $\mathrm{P}$ og $\mathrm{p}$ (dernedimellem versus *dernedmellem). 
Derimod ville følgende ræsonnement kunne redegøre for de data jeg har fremlagt: Da ikke-i-præpositioner ikke kan tage et lokativt pronomen, men $i$-præpositioner godt kan (se tabel 2), og da p ikke kan tage et lokativt pronomen når det kombineres med $\mathrm{P}$ (se paragraffen ovenfor), er det en plausibel antagelse at det lokative pronomen flytter til en position højere oppe til venstre for $\mathrm{p}$, fx i derhenimellem. Hvis vi betragter dataene på denne måde, viser den midterste spalte og den tredje spalte i tabel 4 at der er en afhængighed mellem det lokative pronomen og P.

Jeg antager for nærværende at det er pP-spec som det lokative pronomen flytter til (selvom jeg ikke vil lægge mig fast på det). Derivationen ser skematisk således ud:

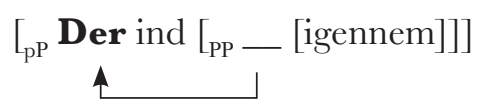

Det kan yderligere ses at pronominet er inden for pP fordi det kan undergå flytning under kløvning sammen med p og P:

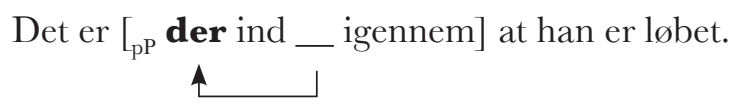

Jeg har således ikke kun argumenteret for at det lokative pronomen rent faktisk flytter, men at det flytter til en position inden for præpositionalfrasen (muligvis til pP-spec). Bemærk yderligere at det lokative pronomen kan flytte ud af præpositionalfrasen:

$$
\text { Der er han løbet }{ }_{p \mathrm{p}} \text { ind igennem.] }
$$

Sammenholdt med flytningen til pP-spec, se (20) og (21), og flytningen ud af præpositionalfrasen, se (22), er det en plausibel antagelse at det lokative pronomen flytter via denne position inden det forlader præpositionsfrasen helt:

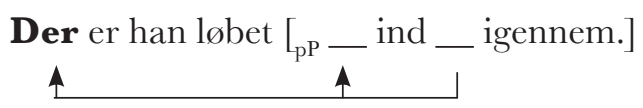

Der er yderligere evidens for at det lokative pronomen flytter til en intern position inden for præpositionalfrasen. Dette gælder komplekser som udenfor, nedenfor og ovenpå: 
(24a) Der uden _ for (*deruden)

(24b) Der neden _ for (*derneden)

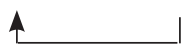

(24c) Der oven _ på (*deroven)

Det er ikke førsteleddet (som kan antages for at være små p'er) der er ansvarligt for at tage det lokative pronomen, men det er hhv. for og på. I disse tilfælde kunne man dog også antage at det er hele kompositummet som tager det lokative pronomen, men det ville i så fald ikke kunne sættes i forbindelse med analysen ovenfor.

Lad mig opsummere hovedargumentet: I dansk er der en række (nær-) synonyme P'er: $i$-præpositioner og ikke- $i$-præpositioner. Den førstnævnte gruppe tager lokative pronominer; den sidstnævnte gør ikke. Hvis disse P'er indledes af $\mathrm{p}$, er det kun ved $i$-præpositionerne at det lokative pronomen kan forekomme. Dette lokative pronomen står til venstre for p. Da det lokative pronomen kan forlade pP'en, er det plausibelt at flytningen er foregået gennem denne position, se (23), gentaget som (25a) nedenfor. Derivationen i (25b) er derimod ikke mulig da det lokative pronomen aldrig selekteres af ikke-i-præpositionen:

(25a) Der er han løbet $\left[{ }_{\mathrm{p} p}\right.$ _ ind _ igennem. $]$

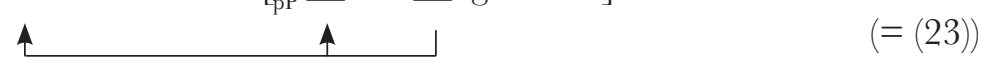

(25b) *Der er han løbet ${ }_{\mathrm{p} p}$ _ ind _ gennem. $]$

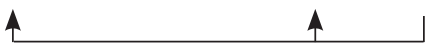

\subsection{Udestående spørgsmål}

I dette underafsnit vil jeg kort nævne en række spørgsmål som analysen ovenfor rejser.

Hvis det er rigtigt at et element flytter til en mellemlandingsposition inden det forlader præpositionalfrasen, er det i princippet muligt at ekstrapolere analysen til almindelige P-komplementer, dvs. at almindelige P-komplementer også går igennem den eller de samme positioner som det lokative pronomen. Der mangler dog en forklaring på hvorfor disse 
P-komplementer ikke kan forblive i mellemlandingspositionen, fx *Han er lobet porten ind igennem.

Et andet åbent spørgsmål er hvordan afledningen ser ud ved præpositionsstranding (Herslund 1984) hvor P ikke kan tage et lokativt pronomen, og hvor der ikke er noget $\mathrm{p}$ til stede, fx Hvilken port er han labet gennem?. Flytter P-komplementet direkte ud, eller flytter det igennem en position i præpositionalfrasen?

Det er også et åbent spørgsmål om $i$-præpositionerne er monomorfemiske. Jeg har her blot præsenteret $i$-præpositioner som simple P'er. Det ville dog være noget af et tilfælde hvis $i$-formerne og ikke-i-formerne systematisk har forskellige morfosyntaktiske egenskaber, og at dette ikke beror på noget strukturelt. Da $i$ i fri form kan tage lokative pronominer, fx deri i deri lå sagens kerne, er det fristende at analysere $i$ 'et som en slags præpositionel kerne.

\section{P-til-p-flytning (P inkorporerer i p)}

Argumenterne ovenfor for flytningen af det lokative pronomen ville stå stærkere hvis man kunne finde eksempler på at det lokative pronomen står mellem p og P, dvs. ned-der-imellem. Tilstedeværelsen af denne streng ville bestyrke ideen om flytning af det lokative pronomen fordi det bliver synligt at det lokative pronomen kan stå i den position som jeg argumenterer at den flytter fra.

Jeg vil argumentere for at vi i mange tilfælde ikke finder denne streng fordi $\mathrm{P}$ inkorporerer i p. Dette kan illustreres på følgende måde:

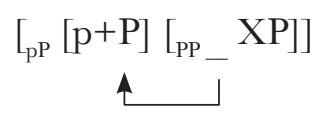

Denne flytning er blevet foreslået $\mathrm{i}$ andre sprog af forskellige lingvister ( $\mathrm{fx}$ Jónsson 2008; Kitada 2010; Riemsdijk 1990), så ideen er på ingen måde original. I de fleste tilfælde er denne flytning ikke synlig da P ikke flytter hen over noget synligt materiale, og fordi den inkorporerer til højre for $\mathrm{p}$. P-til-p-flytning kan derfor kun infereres ved de konsekvenser som en sådan flytning ville medføre. Den medfører at intet materiale kan stå imellem de to størrelser, herunder et lokativt pronomen: ${ }^{9}$

9 Jeg antager at ekskorporation af p ikke er mulig da det komplicerer analysen. Derudover ville ekskorporation trække tæppet væk under forklaringen på hvorfor p og P ikke kan skilles ad (se eksemplerne i dette afsnit). 
(i) Det lokative pronomen kan ikke stå imellem p og P selvom P kan licensere det lokative pronomen.

Der er dog to komplikationer at tage højde for: For det første er det ikke sikkert at strengen ' $p+\mathrm{P}+\mathrm{XP}$ ' har strukturen som i (1), gentaget nedenfor:

$$
\left.{ }_{\mathrm{pP}} \mathrm{p}[\mathrm{pP}[\mathrm{P} X \mathrm{XP}]]\right] \quad(=(1))
$$

Det er potentielt muligt at $\mathrm{p}$ ikke tager den efterfølgende PP som komplement. Se først nedenstående eksempel, der viser at $\mathrm{p}$ kan være efterfulgt af en PP, men behøver ikke at være det: ${ }^{10}$

$$
\text { Frøen sprang ned (i æsken). }
$$

Hvis PP'en ikke er obligatorisk, er det muligt at den ikke er komplement til p. Den kunne fx være adjungeret højere oppe. Det betyder at der i princippet er en strukturel tvetydighed. Med PP'en $i$ asken ville fortolkningen at frøen springer ned inde i asken i princippet være mulig, fx hvis der er en afsats at springe fra inde i æsken. I esken ville i så fald angive den lokation hvorfra frøen foretager sit spring. Med denne fortolkning ville PP'en $i$ asken ikke være komplement til ned. Dog er denne fortolkning ikke plausibel selvom den i princippet er mulig; en fortolkning hvor æsken er mål for frøens spring, er mere plausibel. I dét tilfælde ville PP'en være komplement til p.

Denne strukturelle tvetydighed kan også komme til udtryk ved intonationsmønstret. Hvis der er et intonationsbrud efter p således at PP'en er en intonationsenhed uden $\mathrm{p}$, forbedrer det acceptabiliteten for det intervenerende lokative pronomen. Hvis en konstituent ofte er en intonationsenhed, og en intonationsenhed ofte er en konstituent, tyder det på at PP'en ikke danner en konstituent med p. Hvis der derimod ikke er et intonationsbrud efter p, dvs. at 'p + PP' er en intonationsenhed, tyder det på at denne streng er en konstituent.

10 Et lignende problem er til stede ved fra-PP'er, som er kompatible med statisk p, og som marginalt tillader at et lokativt pronomen kan stå mellem p og fra:

(i) ? Han kom nede derfra.

Disse egenskaber er specielle for fra-PP'er, og ifølge Nielsen (1978: 135) er statisk p ikke kerne i 'p + fra-PP'-strengen. 
Hvis PP'en ikke er komplement til p, betyder det at det lokative pronomen kan stå imellem p og P:

\section{Frøen sprang ned deri.}

Den teoretiske grund til at det lokative pronomen kan stå imellem p og $\mathrm{P}$ hvis $\mathrm{p}+\mathrm{PP}$ ikke er en konstituent, er at P ikke kan inkorporere i p: Forudsætningen for inkorporation er at der er lokal 'c-kommando' mellem kernerne (Baker 1988; Travis 1984: 131). Hvis p + PP ikke danner en konstituent, er der ingen lokal c-kommando mellem p og P. Det medfører at P-til-p-inkorporation ikke kan finde sted, og dermed er der ikke noget til hinder for at det lokative pronomen kan stå mellem p og $\mathrm{P}$.

En lappeløsning på denne komplikation er udelukkende at bruge hen, henne, om og oure som $\mathrm{p}$ i sine tests fordi de næsten altid obligatorisk tager en PP. På den måde sikres det at den efterfølgende PP er komplement til p. ${ }^{11} \mathrm{Jeg}$ vil i det følgende primært bruge hen og henne. Det er dog utilfredsstillende kun at bruge disse p'er da det kunne tænkes at de har nogle idiosynkratiske træk som forvrænger grammatikalitetsvurderingerne ( $\mathrm{fx}$ kan de dårligt topikalisere da de ikke har noget retningsmæssigt modstykke som fx i op versus ned).

Den anden komplikation er at strengen 'lokativt pronomen $+\mathrm{p}+$ P' i mange tilfælde i sig selv er degraderet:

(30a) (?) Købmanden flyttede der-hen-til.

(30b) (?) Købmanden kørte der-ud-i.

Dette kan henføres til en generel restriktion på at $\mathrm{P}$ kun kan være til stede hvis den tilfører en vis semantik (og under forudsætning af at $\mathrm{P}$ af andre årsager kan udelades), eller hvis dens semantik er kontrastiv, se Jaworska (1986: 359). Sammenlign (31a) med (31b): P er ikke licenseret i (31a) da P ikke bidrager med nogen semantik eller sættes i kontrast; (31b) er derimod bedre end (31a) pga. kontrasteringen:

11 Lars Heltoft (pers. kommunikation.) foreslår eksemplet set jer hen derimellem som et problem for min analyse da det lokative pronomen står imellem p og P. Det er dog værd at notere sig at hen i dette tilfælde ikke behøver at tage en PP, fx sat jer hen og vent på mig. Det betyder at den efterfølgende PP i princippet kan være adjungeret til en højere projektion. Derfor er der ikke noget til hinder for at det lokative pronomen står imellem p og P. 
(31a) ? In Poland was safe

(31b) IN Poland was safe, but OUTSIDE Poland was most dangerous.

(Jaworska 1986: 359)

Den samme tankegang kan overføres til dansk:

(32a) Købmanden flyttede der-hen

(32b) Købmanden kørte der-ud

(30a) og (30b) er (nær-)synonyme med (32a) og (32b). Dette er klarest ved (30a) og (32a): Der er allerede en retningsbetydning i derhen, og til angiver udelukkende en retningsbetydning. I følgende minimalpar er P's tilstedeværelse vigtig i en situation hvor containerbetydningen er stærkt markeret, men ikke hvis containerbetydningen er afbleget eller ikke er til stede:

(33a) Vil du have den der-ned-i?

(33b) Vil du have den derned?

(33a) er acceptabel hvis der refererer til en kasse eller en æske, men ikke til en skov eller et værelse. Selvom strengen 'lokativt pronomen $+\mathrm{p}+\mathrm{P}$ ' således i mange tilfælde er stærkt degraderet, er der stadig klar forskel på dén streng (34a) og strengen med det lokative pronomen mellem p og P (34b):

(34a) (?) Købmanden flyttede der-hen-til.

(34b) * Købmanden flyttede hen-der-til.

De to komplikationer, a) at den efterfølgende PP ikke nødvendigvis er komplement til p, og b) at strengen 'lokativt pronomen $+\mathrm{p}+\mathrm{P}$ ' i sig selv nogle gange er degraderet, skal man tage højde for. Gør man det, kan den relevante kontrast mellem (34a) og (34b) forklares.

Den anden forudsigelse som P-til-p-flytning medfører, angår adverbialer mellem p og P:

(ii) Adverbialer kan ikke stå mellem p og $\mathrm{P}$.

Denne forudsigelse kompliceres også af at den efterfølgende PP ikke behøver at være kerne til p. Bortset fra det ser den ud til at være rigtigt: Som vist nedenfor kan adverbialerne direkte og 2 kilometer stå foran hen, men ikke imellem hen og imod: 
(35a) Vi kørte 2 kilometer/direkte hen imod stranden.

(35b) *Vi kørte hen direkte/2 kilometer imod stranden.

En tredje forudsigelse ved P-til-p-analysen er desuden:

(ii) Den efterfølgende PP kan ikke flytte og dermed strande lille p.

Hvis $\mathrm{P}$ inkorporerer i p, kan P ikke flytte med sit komplement og dermed strande lille p. Stranding af lille p er i princippet muligt, se (37a) - (37b), så det er ikke derfor at (38) er ugrammatisk: ${ }^{12}$

(36) Katten sad henne i et hjørne.

(Tilpasset fra https://www.familiejournal.dk/livshistorier/dyrevenner/en-laeser-fortaeller-jeg-fik-en-levende-julegave)

(37a) (?) Hvilket hjørne sad katten henne i

$\uparrow$

(37b) Hvor sad katten henne

个

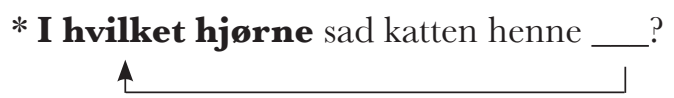

Den fjerde forudsigelse som P-til-p-flytning giver, er:

(ii) Lille p kan ikke stå i CP-spec alene.

Denne forudsigelse kan være begrundet $\mathrm{i}$ at en kerne, herunder p, ikke kan flytte til CP-spec (fundamentfeltet), som er en XP-position (Chomsky 1986: 4). Men det er muligt at forestille sig at PP'en flytter ud af pP, fx ved ekstraposition mod højre, og at pP'en efterfølgende undergår såkaldt 'remnant movement' (flytning af en konstituent som en mindre konstituent allerede er flyttet ud af) til CP-spec:

12 (37b) er ikke nødvendigvis et problem for tesen om P-til-p-inkorporation da man kan antage at der er en usynlig default P til stede (Nguyen 2017 kap. 4). Ved analogi med de eksempler hvor P inkorporerer i p, kunne man antage at den usynlige $\mathrm{P}$ også inkorporerer i p, og at det lokative pronomen flytter. 
(39a) $\quad\left[{ }_{\mathrm{CP}} \cdots\left[{ }_{\mathrm{pP}} \mathrm{p} \_\ldots\right.\right.$

(39b) $\quad\left[{ }_{\mathrm{CP}}\left[{ }_{\mathrm{pP}} \mathrm{P}-\right] \cdots-\cdots \quad[\mathrm{PP}]\right]$
(Ekstraposition af PP)

(Remnant movement af $\mathrm{pP}$ )

Men P-til-p-flytning forudsiger at p og P ikke kan adskilles, heller ikke under ekstraposition med efterfølgende remnant movement. Under alle omstændigheder er det i princippet muligt at $\mathrm{p}$ kan stå i CP-spec når det kontrasteres, og når det er semantisk transparent (se Vikner 2017: 375; Zeller 2002: 39-40; og Haiden 2006: 360):

(40a) Herstedvester har ladet Magnus sidde på bænken efter det gule kort, og ... ind har de sat Emre.

(Autentisk eksempel fra Vikner 2017: 375)

(40b) Ned løb han _, ikke op.

Det væsentlige er dog at p ikke kan stå i CP-spec hvis det tager en PP:

$$
\text { ??/* Ind har de sat Emre [ _ [ [pP på banen }] \text {. }
$$

\section{$\uparrow$}

(41b) *Ned løb han [_ [ [pp til huset]], ikke op.

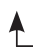

At p kan stå i CP-spec, er således udelukket hvis P-til-p-flytning finder sted. Afledningen som involverer ekstraposition af $\mathrm{PP}+$ remnant movement af pP, er ikke mulig.

Den femte forudsigelse angår koordination:

(v) En PP, hvis den er selekteret af p, kan ikke koordineres med en anden PP som er selekteret af den samme p.

Hvis $\mathrm{P}$ altid inkorporerer i p, så er koordination af PP'er ikke mulig hvis den første konjunkt-PP er obligatorisk indledt af p. P i den anden konjunkt er øjensynlig ikke inkorporeret i p: 

*De løb ind i dalen og i hytten.

Jeg har i dette afsnit argumenteret for P-til-p-flytning. De forudsigelser en sådan flytning medfører, er i overensstemmelse med data.

Til sidst vil jeg kort nævne et potentielt problem i artiklens analyse. I afsnit 2.2. argumenterede jeg for at $\mathrm{p}$ inkorporerer i V, fx i (8), de har $\boldsymbol{u d}$ sendt en meddelelse _ til befolkningen, men i afsnit 4 argumenterede jeg for at $\mathrm{P}$ inkorporerer i p. Problemet i (8) er at P øjensynlig ikke er inkorporeret i p, og at jeg antager at ekskorporation af p er umulig. Man kan dog spekulere om der er noget i grammatikken der fremtvinger enten inkorporation $\mathbf{i}$ eller $\mathbf{a f} \mathrm{p}$.

\section{Sammenfatning}

I denne artikel har jeg behandlet præpositionalfrasens og lokative pronominers syntaks. Hovedpunkterne er følgende:

i. Præpositionalfraser kan have formen $\left[_{\mathrm{pP}} \mathrm{p}\left[{ }_{\mathrm{PP}} \mathrm{PXP}\right]\right.$, hvor retningsadverbiet p er kerne (afsnit 2).

ii. Det lokative pronomen flytter gennem en mellemlandingsposition inden det flytter ud af præpositionalfrasen, jf. kontrasten $i$-præpositioner og ikke-i-præpositioner (afsnit 3).

iii. P flytter op i p (P-inkorporation i p). Det medfører bl.a. at intet kan stå imellem disse to elementer, og at PP'en ikke kan flytte (afsnit 4).

\section{Om forfatteren}

Michael Nguyen er ph.d.-studerende på Institut for Kommunikation og Kultur ved Aarhus Universitet.

\section{Litteratur}

Baker, M. (1988): Incorporation: A theory of grammatical function changing. Chicago \& London: The University Chicago Press.

Chomsky, N. (1986): Barriers. Cambridge, Massachusetts \& London: MIT Press.

Cinque, G. (1999): Adverbs and functional heads: A cross-linguistic perspective. New York \& Oxford: Oxford University Press.

Den Dikken, M. (2010): On the functional structure of locative and directional PPs. I: Mapping spatial PPs: The cartography of syntactic structures 
6. Cinque, G. \& Rizzi, L. (red.), New York: Oxford University Press, 74-126.

Haiden, M. (2006): Verb particle constructions. I: The Wiley Blackwell companion to syntax. Everaert, M. \& Riemsdijk, H. van (red.). Oxford: Blackwell, 344-375.

Hansen, E., \& Heltoft, L. (2011): Grammatik over det danske sprog. København: Syddansk Universitetsforlag.

Herslund, M. (1984): Particles, prefixes and preposition stranding. Nydanske Sprogstudier 14, 34-71. doi:10.7146/nys.v14il4.13331

Hovmark, H. (2007): Danske retningsadverbier og rumlig orientering. Ph.d.-afhandling. Københavns Universitet, København. (https://nors.ku.dk/ publikationer/ph.d.-afhandlinger/henrikhovmarkphdafhandling.pdf 27.02.2019).

Jónsson, J. G. (2008): Preposition reduplication in Icelandic. I: Microvariation in syntactic doubling. Barbiers, S., Koeneman, O., Lekakou, M., \& Ham, van der, M. van der (red.). Bingley: Emerald, 403-417.

Kitada, S. (2010): Feature-inheritance in prepositional phrases. Ms. (http://citeseerx.ist.psu.edu/viewdoc/download?doi=10.1.1.533.8767\&rep=rep

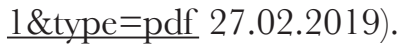

Koopman, H. (2000): Prepositions, postpositions, circumpositions and particles: The structure of Dutch PPs. I: The syntax of specifiers and heads. Collected essays of Hilda 7. Koopman. Koopman, H. (red.). London \& New York: Routledge, 198-256.

Nguyen, M. (2017): Preposition stranding under R-movement in Danish. Upubliceret speciale. Aarhus: Aarhus Universitet.

Nguyen, M. (2019): Extraction of R-pronouns via an intermediate position within the prepositional domain. Snippets 35, 10-12. doi:10.7358/ snip-2019-035-nguy

Nielsen, B. J. (1978): Om stedsadverbium + fra i jyske dialekter. Danske Folkemål, 21, 131-138.

Riemsdijk, H. van. (1978): A case study in syntactic markedness: The binding nature of prepositional phrases. Lisse: The Peter de Ridder Press.

Riemsdijk, H. van. (1990): Functional prepositions. I: Unity in diversity. Festschrift for Simon Dik. Pinkster, H. \& Genee, I. (red.). Dordrecht: Foris, 229-241.

Riemsdijk, H. van, \& Huijbregts, R. (2007): Location and locality. I: Phrasal and clausal architecture: Syntactic derivation and interpretation. In honor of Joseph E. Emonds. Karimi, S., Samiian, V. \& Wilkins, W. K. (red.), Amsterdam \& Philadelphia: John Benjamins, 339-364. 
Rooryck, J. (1996): Prepositions and minimalist case marking. Studies in Comparative Germanic Syntax 2. Thrainsson, H., Epstein, S. \& Peter, S. (red). Dordrecht: Kluwer, 226-256.

Svenonius, P. (1996): The verb-particle alternation in the Scandinavian languages. Upubliceret ms. (ling.auf.net/lingbuzz/000046/current.pdf 27.02.2019). Travis, L. D. (1984): Parameters and effects of word order variation. MIT Press. Thomsen, O. N. (1997): Retningsadverbialer og komplekse prædikater i dansk. I: Selskab for Nordisk Filologi. Arsberetning 1996-1997, 66-84.

Vikner, S. (2017): Germanic verb particle variation. I: Elements of comparative syntax - theory and description. Aboh, E., Haeberli, E., Puskás, G. \& Schönenberger, M. (red.). Berlin: de Gruyter, 371-398. doi:10.1515/9781501504037-014

Zeller,J. (1997): Against overt particle incorporation. University of Pennsylvania Working Papers in Linguistics, 4, 291-307.

Zeller, J. (2002): Particle verbs are heads and phrases. I: Verb-Particle Explorations. Dehé, N., Jackendoff, R., McIntyre, A. \& Urban, S. (red.). Berlin \& Boston: de Gruyter, 233-268. doi:10.1515/9783110902341.233

\subsection{Internetkilder}

https://www.familiejournal.dk/livshistorier/dyrevenner/en-laeser-fortaeller-jeg-fik-en-levende-julegave

https://www.sctknud-gym.dk/media/151991/fysik-a.pdf

KorpusDK 